\title{
The Effect of Growth Conditions on the Respiratory System of a Succinoglucan-producing Strain of Agrobacterium radiobacter
}

\author{
By ALEX CORNISH, ${ }^{1}$ JOHN D. LINTON ${ }^{2} \dagger$ AND COLIN W. JONES ${ }^{*}$ \\ ${ }^{1}$ Department of Biochemistry, University of Leicester, Leicester LE1 7RH, UK \\ ${ }^{2}$ Shell Research Ltd, Sittingbourne, Kent ME9 $8 A G, U K$
}

(Received 9 December 1986; revised 27 March 1987)

\begin{abstract}
The respiratory system of Agrobacterium radiobacter NCIB 11883, a producer of succinoglucan exopolysaccharide under ammonia-limited conditions, was studied following growth in continuous culture $\left(D=0.045 \mathrm{~h}^{-1}\right)$ under glucose, oxygen and ammonia limitation. The respiratory chain contained $b$ - and $c$-type cytochromes, plus two terminal oxidases $\left(a a_{3}\right.$ and $c o$ ) under all growth conditions, and exhibited a low transhydrogenase activity. An inactive apoenzyme form of the quinoprotein glucose dehydrogenase was also present which could be activated by adding pyrroloquinoline quinone (PQQ) to cell suspensions. The activity of the terminal region of the respiratory chain increased approximately fourfold following growth under oxygen limitation, and this was accompanied by a significant increase in the concentration of cytochrome oxidase $c o$. Whole cells exhibited $\rightarrow \mathrm{H}^{+} / \mathrm{O}$ quotients of 5.5-6.3 for the oxidation of endogenous substrate depending on the nature of the growth-limiting nutrient. It is concluded that the respiratory chain energy conservation system of this organism is not significantly modified during ammonia-limited growth to offset the increased energy demands for exopolysaccharide synthesis.
\end{abstract}

\section{INTRODUCTION}

Succinoglucan exopolysaccharides are produced by several members of the genus Agrobacterium (Hisamatsu et al., 1977, 1978) and on hydrolysis yield glucose, galactose, pyruvate, succinate and, in some cases, acetate. The polymer produced by $A$. radiobacter NCIB 11883 contains all these constituents in the molar ratio $7: 1: 1: 1: 0 \cdot 1$ and is synthesized at the highest rate during growth in continuous culture under ammonium limitation at a dilution rate of approximately $0.045 \mathrm{~h}^{-1}$ (Linton et al., 1987b). Carbon-balance and yield data indicate that under these growth conditions polysaccharide production imposes a severe energy burden on the organism, the amount of ATP required for polymer synthesis being almost equal to that needed for production of cell material (Linton et al., 1987 b).

The objective of the present work was to investigate the composition of the respiratory chain of $A$. radiobacter following growth in continuous culture under different nutrient limitations, and to establish whether the energy conservation properties of this organism are modified during ammonia-limited growth in an attempt to offset the additional energy demand for polymer synthesis.

\section{METHODS}

Organism and growth conditions. Agrobacterium radiobacter NCIB 11883 was obtained from Dr J. D. Linton, Shell Research, Sittingbourne, Kent, UK. The organism was grown at $30^{\circ} \mathrm{C}$ under glucose limitation in

† Present address: Koninklijke Shell Laboratorium, Badhuisweg 3, 1003 AA Amsterdam, The Netherlands.

Abbreviations: PQQ, pyrroloquinoline quinone; TMPD, $N, N, N^{\prime}, N^{\prime}$-tetramethyl-p-phenylenediamine; TMBZ, $3,3^{\prime}, 5,5^{\prime}$-tetramethylbenzidine; GDH, glucose dehydrogenase.

0001-3874 C 1987 SGM 
continuous culture $\left(D=0.045 \mathrm{~h}^{-1}\right)$ using a chemically defined medium (Linton et al., $1987 \mathrm{~b}$ ) supplemented with glucose $\left(4 \mathrm{~g} \mathrm{l}^{-1}\right)$, ammonium sulphate $\left(3 \mathrm{~g}^{-1}\right)$ and $0 \cdot 142 \mathrm{~g}$ nitrilotriacetic acid $\mathrm{l}^{-1}$ (steady state biomass

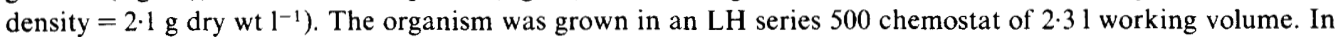
order to achieve ammonia-limited growth the input concentration of ammonium sulphate was reduced to $0.5 \mathrm{~g} \mathrm{l}^{-1}$ (biomass density $=1.2 \mathrm{~g}$ dry wt $\mathrm{l}^{-1}$ ). During oxygen-limited growth the biomass density was maintained at $0 \cdot 5$ $0.8 \mathrm{~g}^{-1}$ by reducing both the air supply to the culture and the extent of agitation. Succinoglucan was produced only during growth under ammonia limitation when the polymer concentration in the medium was $0.98 \pm 0.03 \mathrm{~g} \mathrm{l}^{-1}$ (mean \pm SEM of five determinations).

Preparation of cell suspensions and subcellular fractions. All operations were done at $4{ }^{\circ} \mathrm{C}$ using pre-cooled buffers and glassware. HEPES/KOH buffer $(20 \mathrm{~mm}, \mathrm{pH} 7.0)$ was used throughout this work unless otherwise stated.

Samples withdrawn from glucose-limited cultures were centrifuged at $15000 \mathrm{~g}$ for $15 \mathrm{~min}$. The cell pellet was washed once with a volume of buffer equal to the original culture volume and resuspended to give a cell density of approximately $10 \mathrm{mg}$ dry $\mathrm{wt} \mathrm{ml}^{-1}$. Samples from ammonia-limited cultures containing succinoglucan were diluted with buffer ( 5 vols buffer: 1 vol. culture) before the initial centrifugation to facilitate separation of the cells from the highly viscous polymer. Samples from oxygen-limited cultures contained clumps of cellulose (J. D. Linton, unpublished observation). These were removed before centrifugation by passing the cells through a short column of non-absorbent cotton wool. The same procedures were used to prepare cell suspensions for measurement of $\rightarrow \mathrm{H}^{+} / \mathrm{O}$ quotients, except that cells were washed and resuspended in $0.5 \mathrm{~mm}-\mathrm{HEPES}(\mathrm{pH} 7 \cdot 0)$ containing $140 \mathrm{~mm}-$ $\mathrm{KCl}$.

Cell-free extracts were prepared by sonicating washed-cell suspensions (cooled using an ice/water mixture) using repeated bursts of ultrasound $(6 \times 15 \mathrm{~s}$ bursts, $1 \mathrm{~min}$ interval between bursts). Whole cells and debris were pelleted by centrifuging at $15000 \mathrm{~g}$ for $15 \mathrm{~min}$, and the cell-free extract was removed and stored on ice. Cell-free extracts were separated into soluble and membrane fractions using high-speed centrifugation ( $150000 \mathrm{~g}$ for $1 \mathrm{~h}$ ). Following removal of the supernatant, the membrane pellet was carefully resuspended using a glass homogenizer, then recentrifuged and finally resuspended in fresh buffer to yield the washed-membrane fraction.

Measurement of oxygen uptake. Rates of oxygen consumption $\left(q_{\mathrm{O}_{z}}\right)$ were measured at $30^{\circ} \mathrm{C}$ using a Rank oxygen electrode. The reaction chamber contained $3.8 \mathrm{ml}$ buffer, to which were added $0 \cdot 1 \mathrm{ml}$ cell suspension $(0 \cdot 5-1.0 \mathrm{mg}$ dry wt cells) and finally $0.1 \mathrm{ml}$ of substrate $(40 \mu \mathrm{mol}$ carbohydrate substrates or $20 \mu \mathrm{mol}$ ascorbate plus $4 \mu \mathrm{mol}$ TMPD). For some experiments cells were incubated with $12 \mu \mathrm{M}-\mathrm{PQQ}$ plus $10 \mathrm{mM}-\mathrm{MgCl}_{2}$ for 5 min before addition of substrate to allow for complete activation of quinoprotein glucose dehydrogenase (GDH). $q_{\mathrm{O}_{2}}$ values were corrected for endogenous rates of respiration measured before addition of substrate and, in the case of ascorbateTMPD, for autoxidation. The oxygen concentration of air-saturated buffer at $30^{\circ} \mathrm{C}$ was taken as $230 \mu \mathrm{M}$.

In situ measurements of $q_{\mathrm{O}}$. In situ $q_{\mathrm{O}}$, values quoted in the text were taken from Linton et al. (1987b).

Measurement of $\rightarrow H^{+} \mathrm{O}$ quotients. The organism was incubated at $30^{\circ} \mathrm{C}$ in a closed vessel of $5 \mathrm{ml}$ working volume containing $4.7 \mathrm{ml}$ cell suspension ( $25 \mathrm{mg}$ dry wt cells) prepared in $0.5 \mathrm{~mm}$-HEPES (pH 7.0)/140 mM-KCl. Potassium thiocyanate was added to give a final concentration of $180 \mathrm{mM}(0.3 \mathrm{ml}$ of a $3 \mathrm{M}$-stock solution). The anaerobic suspension was mixed using a magnetic stirrer and the $\mathrm{pH}$ was monitored continuously using a glass combination micro-electrode (Russell $\mathrm{pH} \mathrm{Ltd}$ ) connected to a chart recorder. After 30 min incubation, $21 \mu \mathrm{l}$ of a freshly prepared solution of carbonic anhydrase $\left(12 \mathrm{mg} \mathrm{ml}^{-1}\right)$ was added to the suspension, the $\mathrm{pH}$ of which was then adjusted to 6.5 by the addition of $1 \mathrm{M}-\mathrm{HCl}$ or $1 \mathrm{M}-\mathrm{KOH}$ as appropriate and allowed to stabilize. The cell suspension was pulsed with oxygen by injecting known volumes $(10-35 \mu \mathrm{l})$ of $140 \mathrm{mM}-\mathrm{KCl}$ saturated with air at $30^{\circ} \mathrm{C}$, and the resulting $\mathrm{pH}$ changes were recorded. The oxygen concentration of the air-saturated $\mathrm{KCl}$ solution at $30^{\circ} \mathrm{C}$ was taken as $225 \mu \mathrm{M}$. The $\mathrm{pH}$ recorder was calibrated by injecting small volumes $(1-6 \mu \mathrm{l})$ of an anaerobic solution of $10 \mathrm{~mm}-\mathrm{KOH}$.

Cytochrome difference spectra. These were recorded using a Perkin Elmer $\lambda-5$ split beam spectrophotometer. The organism contained relatively low concentrations of cytochromes and it proved difficult to obtain good quality spectra using whole-cell suspensions. Measurements were therefore done on crude extracts obtained by briefly centrifuging disrupted cells $(13000 \mathrm{~g}$ for $2 \mathrm{~min}$ ) using an Eppendorf microfuge. The cytochrome profile of the samples was not affected by this treatment and less than $10 \%$ of the total cytochrome was lost in the pellet. Reduced-minus-oxidized spectra were recorded following oxidation of the contents of a reference cuvette using $10 \mu \mathrm{l}$ of a saturated solution of ferricyanide and reduction of the contents of a sample cuvette using a few grains of dithionite. Concentrations of cytochromes were estimated using the following molar absorption coefficients $\left(\mathrm{mM}^{-1} \mathrm{~cm}^{-1}\right)$ : cytochrome $c$ 17.3 $(552-538 \mathrm{~nm})$; cytochrome $b \quad 17.5(560-575 \mathrm{~nm})$; cytochrome $a a_{3} 11 \cdot 7(604$ $625 \mathrm{~nm}$ ) (see Jones \& Poole, 1985). In order to record CO-binding spectra (reduced + CO-minus-reduced), a $2 \mathrm{ml}$ sample was reduced using a few grains of dithionite, divided into two $1 \mathrm{ml}$ portions and used to record the reducedminus-reduced spectrum. The contents of the sample cuvette were then bubbled with carbon monoxide for 1 min after which time a baseline-corrected $\mathrm{CO}$-binding spectrum was recorded.

$S D S-P A G E$. Electrophoresis of proteins was done using $12 \%(\mathrm{w} / \mathrm{v})$ acrylamide gels according to the method of Laemmli (1970). Samples of cells (about $500 \mu \mathrm{g}$ dry wt) or membranes (about $100 \mu \mathrm{g}$ protein) were boiled for $4 \mathrm{~min}$ 
in dissolving buffer (Laemmli, 1970) without mercaptoethanol, and were then stained for haem-associated peroxidase activity using the method of Thomas et al. (1976).

Assay of cell-free GDH activity. This was done polarographically in the presence of $12 \mu \mathrm{M}-\mathrm{PQQ}$ as described by van Schie et al. (1985) except that phenazine ethosulphate (1 mM) was used to mediate electron flow between GDH and oxygen.

Assay of membrane-bound transhydrogenase activity. This was done using washed-membranes as described by Jones et al. (1975).

Measurement of protein. This was done using the modified Lowry assay of Peterson (1977) using bovine serum albumin as a standard.

Measurement of bacterial dry weight. Suspensions of $A$. radiobacter from different nutrient limitations were diluted using distilled water and the optical density was measured at $600 \mathrm{~nm}$. The dry weights of cell suspensions were determined by interpolation using the appropriate optical density/dry weight standard curves.

Chemicals. The trisodium salt of PQQ was a gift from Professor J. A. Duine, University of Delft, The Netherlands. All other chemicals were from Fisons and were of the highest grade available.

Presentation of data. Where appropriate, values have been quoted as the mean \pm SEM with the number of determinations in parentheses.

\section{RESULTS}

Effects of nutrient limitation on rates of substrate-dependent oxygen consumption by washed cell suspensions

Rates of oxygen consumption $\left(q_{\mathrm{O}_{2}}\right)$ with various substrates were measured using washed cells prepared from cultures grown under different nutrient limitations (Table 1). Significant rates of respiration were observed in the absence of added substrate irrespective of the conditions under which the organism had been grown; these endogenous rates are probably due to mobilization of an intracellular polyglucose storage polymer that $A$. radiobacter produces constitutively and which accounts for about $3 \%$ of the bacterial dry weight during growth under glucose-limited growth and up to $30 \%$ of the dry weight during ammonia-limited growth (J. D. Linton, unpublished observations; Linton et al., 1987b).

$q_{\mathrm{O}}$, values with glucose as substrate were largely independent of the growth-limiting nutrient [75-96 ng-atom $\mathrm{O} \mathrm{min}^{-1}(\mathrm{mg} \text { dry wt })^{-1}$ ]. These values were significantly higher than the in situ value measured during glucose-limited growth at a dilution rate of $0.045 \mathrm{~h}^{-1}$ [42 ng-atom $\mathrm{O}$ $\min ^{-1}$ (mg dry wt $\left.)^{-1}\right]$ but were similar to the in situ value measured during ammonia-limited growth [ $85 \mathrm{ng}$-atom $\mathrm{O} \mathrm{min} \mathrm{m}^{-1}(\mathrm{mg} \text { dry } \mathrm{wt})^{-1}$ ]. The $q_{\mathrm{O}}$, values of washed cells prepared from all three types of nutrient limitation increased significantly when incubated with PQQ before addition of glucose, suggesting that $A$. radiobacter possesses the inactive (apoenzyme) form of quinoprotein GDH which is activated on adding the PQQ cofactor as has also been found for other Gram-negative organisms (Hommes et al., 1984; van Schie et al., 1984). Consistent with this proposal is the observation that $q_{\mathrm{O}_{2}}$ values measured with xylose, an alternative substrate for quinoprotein GDH (Hauge, 1960), also increased following addition of PQQ, and GDH activity [equivalent to $211 \mathrm{nmol}$ glucose oxidized $\min ^{-1}(\mathrm{mg} \text { protein })^{-1}$ ] could be measured in cell-free extracts of glucose-limited cells using the polarographic method of van Schie et al. (1985) provided that PQQ was added to the assay system. Furthermore, Linton et al. (1987a)

Table 1. $q_{O}$, values for the oxidation of different respiratory substrates by washed cell suspensions of $A$. radiobacter following growth in continuous culture under different nutrient limitations

\begin{tabular}{|c|c|c|c|c|c|}
\hline \multirow{3}{*}{$\begin{array}{l}\text { Growth- } \\
\text { limiting } \\
\text { nutrient }\end{array}$} & \multirow{3}{*}{$\begin{array}{l}\text { Substrate } \\
\text { added }\end{array}$} & \multicolumn{4}{|c|}{$q \mathrm{O}_{2}\left[\right.$ ng-atom $\left.\mathrm{O} \min ^{-1}(\mathrm{mg} \text { dry } w t)^{-1}\right]$} \\
\hline & & \multirow{2}{*}{$\begin{array}{c}\text { None } \\
\text { (endogenous } \\
\text { respiration) }\end{array}$} & \multicolumn{2}{|c|}{ Glucose } & \multirow[b]{2}{*}{ Ascorbate-TMPD } \\
\hline & & & $-\mathrm{PQQ}$ & $+\mathrm{PQQ}$ & \\
\hline Glucose & & $15 \pm 2 \quad(9)$ & $96 \pm 4(8)$ & $210 \pm 12(3)$ & $483 \pm 26(10)$ \\
\hline Oxygen & & $19 \pm 1(12)$ & $94 \pm 5(5)$ & $278 \pm 24(3)$ & $1780 \pm 61$ \\
\hline Ammonia & & $14 \pm 1(12)$ & $75 \pm 4(5)$ & $154 \pm 7(5)$ & $396 \pm 30$ \\
\hline
\end{tabular}




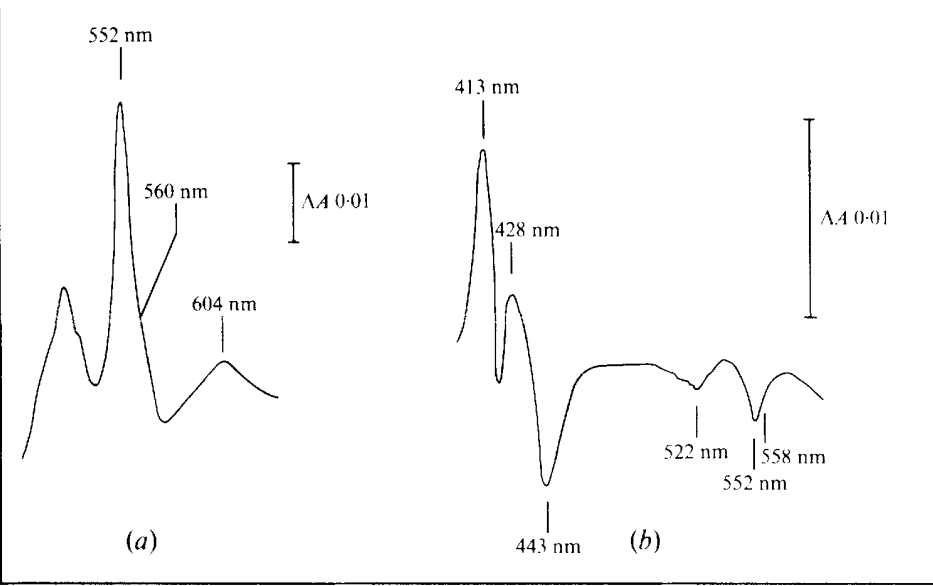

Fig. 1. Cytochrome spectra of $A$. radiobacter grown in continuous culture $\left(D=0.045 \mathrm{~h}^{-1}\right)$ under glucose limitation. Washed cell suspensions $\left(10 \mathrm{mg}\right.$ dry wt $\left.\mathrm{ml}^{-1}\right)$ were prepared for spectral analysis as described in Methods. (a) Dithionite-reduced-minus-ferricyanide-oxidized difference spectrum; $(b)$ dithionite-reduced $+\mathrm{CO}$-minus-dithionite-reduced difference spectrum.

Table 2. Cytochrome content of A. radiobacter following growth in continuous culture under different nutrient limitations

\author{
Growth-limiting \\ nutrient
}

Glucose

Oxygen

Ammonia

$$
\begin{gathered}
\text { Total } \\
\text { cytochrome } c \\
178 \pm 8(5) \\
272 \pm 18(3) \\
144 \pm 8(3)
\end{gathered}
$$

Total

cytochrome $b$ [pmol (mg dry wt $)^{-1}$ ]

$$
\begin{array}{r}
99 \pm 12(5) \\
200 \pm 14(3) \\
75 \pm 7(3)
\end{array}
$$

Cytochrome $a a_{3}$

$$
\begin{aligned}
& 29 \pm 3(5) \\
& 34 \pm 9(3) \\
& 26 \pm 7(3)
\end{aligned}
$$

reported that growing cultures and washed-cell suspensions of this strain of $A$. radiobacter produce gluconate (the product of GDH-catalysed glucose oxidation) at high rates [55-100 nmol $\min ^{-1}(\mathrm{mg} \text { dry } \mathrm{wt})^{-1}$ ] following addition of PQQ.

$A$. radiobacter readily oxidized ascorbate-TMPD, the $q_{\mathrm{O}}$, being approximately fourfold higher when the organism was grown under oxygen limitation compared with either glucose or ammonia limitation (Table 1), thus indicating that the activity of the terminal segment of the respiratory chain is regulated by the availability of oxygen.

\section{Cytochrome analysis}

Analysis of the cytochrome complement of $A$. radiobacter using difference spectrophotometry revealed that the organism contained $b$ - and $c$-type cytochromes plus cytochrome oxidase $a a_{3}$ during growth under glucose limitation as indicated by peaks in the reduced-minus-oxidized difference spectrum at $552 \mathrm{~nm}$ and $604 \mathrm{~nm}$ representing the $\alpha$-bands of cytochromes $c$ and $a a_{3}$ respectively, and by an inflexion at $560 \mathrm{~nm}$ due to the $\alpha$-band of cytochrome $b$ (Fig. $1 a$ ). The absolute concentration of each type of cytochrome was similar in cells grown at high ambient concentrations of oxygen (i.e. under glucose or ammonia limitation), but when the organism was grown under oxygen limitation the concentrations of the $b$ - and $c$-type cytochromes approximately doubled whilst the concentration of cytochrome $a a_{3}$ remained constant (Table 2).

The nature of the potential terminal oxidases present under different nutrient limitations was investigated further by recording reduced $+\mathrm{CO}$-minus-reduced difference spectra (Fig. $1 b$ ). All of the latter exhibited a peak at $428 \mathrm{~nm}$ and a trough at $443 \mathrm{~nm}$ indicating that cytochrome $a_{3}$ was present under all growth conditions at a concentration of $9-15 \mathrm{pmol}(\mathrm{mg} \text { dry wt })^{-1}$. Most CO-binding spectra also contained peaks at $413 \mathrm{~nm}$ and troughs at $522 \mathrm{~nm}$ and $552 \mathrm{~nm}$ which 

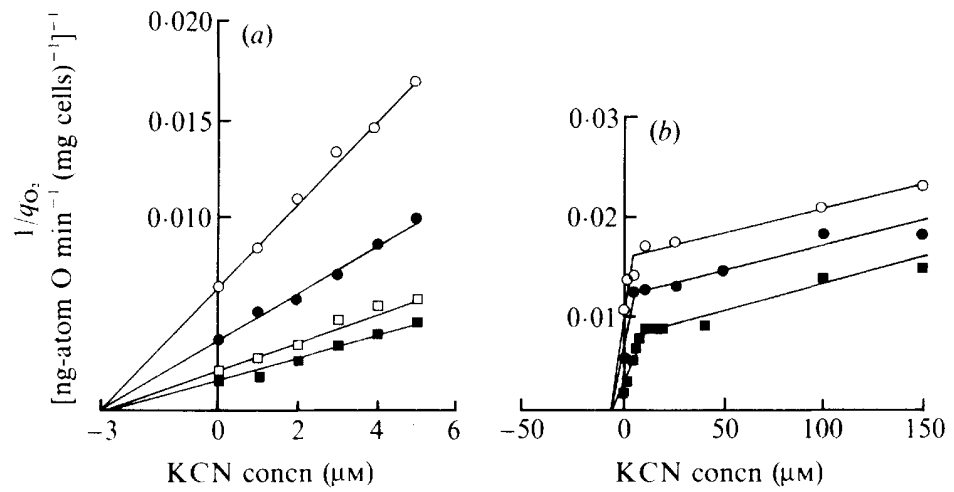

Fig. 2. Dixon plots showing the effect of cyanide on the oxidation of ascorbate-TMPD by whole cells of $A$. radiobacter grown in continuous culture $\left(D=0.045 \mathrm{~h}^{-1}\right)$ under glucose limitation. The concentrations of TMPD used were $100 \mu \mathrm{M}(0), 200 \mu \mathrm{M}(\bullet), 500 \mu \mathrm{M}(\square)$ and $1000 \mu \mathrm{M}(\mathbf{E})$. Plots in $(a)$ and $(b)$ were obtained using different batches of cells.

were due to cytochrome $c$ binding carbon monoxide; this phenomenon, which has been observed with many bacterial c-type cytochromes, is probably due to displacement of one of the ligands coordinating the haem and is not in itself indicative of an oxidase function. Spectra of cells grown under oxygen limitation sometimes contained an additional peak at $418 \mathrm{~nm}$ and a shoulder at $558 \mathrm{~nm}$, which suggest the presence of an $o$-type oxidase, but these peaks were often obscured by the peaks at $413 \mathrm{~nm}$ and $552 \mathrm{~nm}$ due to cytochrome $c$. In view of our failure to detect an $o$-type oxidase consistently by means of spectral analysis it was decided to investigate the cytochrome complement by first separating the polypeptides using SDS-PAGE and then staining for haem-associated peroxidase activity using TMBZ (Thomas et al., 1976). Washed cells and membranes prepared from cultures grown under all nutrient limitations contained two polypeptides $\left(M_{\mathrm{r}} 29000\right.$ and 24000$)$ which stained for haem and were present at much higher concentrations following growth under oxygen limitation (not shown). The $M_{\mathrm{r}}$ values of these polypeptides are similar to those of cytochrome oxidase co components isolated from other Gram-negative organisms (see Discussion).

\section{Analysis of the terminal segment of the respiratory chain}

The composition of the terminal segment of the respiratory chain was investigated further by examining the effect of cyanide on the oxidation of ascorbate-TMPD since it has previously been observed that TMPD oxidation is inhibited by cyanide in an uncompetitive fashion when respiratory chains are terminated by cytochrome oxidase $a a_{3}$ whereas non-competitive inhibition is observed with $o$-type oxidases (Jones, 1973; Carver \& Jones, 1983). Dixon plots constructed using cells grown under glucose limitation showed two distinct types of inhibition: non-competitive inhibition $\left(K_{\mathrm{i}}=4 \cdot 1 \pm 0 \cdot 6 \mu \mathrm{M} ; n=5\right)$ was observed at low concentrations of cyanide $(0-10 \mu \mathrm{M})$ whilst uncompetitive inhibition $\left(K_{\mathrm{i}} \leqslant 80 \mu \mathrm{M}\right)$ was noted when the cyanide concentration exceeded $10 \mu \mathrm{M}$ (Fig. $2 a, b$ ). Similar Dixon plots were obtained with cells grown under ammonia or oxygen limitation, although in the latter case the uninhibited rate of TMPD oxidation was considerably higher (see Table 1).

These observations suggest that a considerable proportion of the electron flow from TMPD to oxygen can occur by way of an oxidase (probably cytochrome $c o$ ) that is highly sensitive to cyanide; when the concentration of cyanide exceeds $10 \mu \mathrm{M}$, this oxidase is rendered inactive and electron flow continues by way of cytochrome $a a_{3}$. The effect of cyanide on glucose-dependent respiration was also examined using cells grown under glucose and oxygen limitation and with both types of cells there was little diminution in the measured rate of oxygen consumption until the cyanide concentration exceeded $75 \mu \mathrm{M}\left(\mathrm{I}_{50}=100 \mu \mathrm{M}\right.$ for glucose-limited cells and $95 \mu \mathrm{M}$ for oxygen-limited cells). Electron flow from glucose to oxygen is evidently not impeded at 
Table 3. $\rightarrow H^{+} / O$ quotients for the oxidation of endogenous substrates by washed cell suspensions of $A$. radiobacter following growth in continuous culture under different nutrient limitations

\author{
Growth-limiting \\ nutrient
}

Glucose

Oxygen

Ammonia

$$
\begin{gathered}
\rightarrow \mathrm{H}^{+} / \mathrm{O} \text { quotient } \\
{\left[\text { ng-ion } \mathrm{H}^{+}(\text {ng-atom } \mathrm{O})^{-1}\right. \text { ] }}
\end{gathered}
$$$$
6 \cdot 3 \pm 0 \cdot 1(18)
$$$$
5 \cdot 5 \pm 0 \cdot 1 \quad(6)
$$$$
5 \cdot 9 \pm 0 \cdot 2
$$

\section{$t_{3}$ for collapse of \\ $\mathrm{H}^{+}$gradient}

(s)

$37 \cdot 5 \pm 5 \cdot 0(10)$

$33.5 \pm 1 \cdot 5(6)$

$10 \cdot 0 \pm 1 \cdot 0 \quad(4)$

concentrations of cyanide which render cytochrome co inactive, presumably because cytochrome $a a_{3}$ is not saturated by the relatively low rate of electron transfer.

\section{Measurement of $\rightarrow \mathrm{H}^{+} \mathrm{O}$ quotients}

This was done for suspensions of $A$. radiobacter prepared from cultures grown under glucose, oxygen and ammonia limitation (Table 3 ). These values were obtained using cells respiring endogenous substrate (probably a glucose homopolymer; see above) which has been assumed to donate electrons to the respiratory chain via NAD $(\mathrm{P}) \mathrm{H}$. Unfortunately, it did not prove possible to deplete cells of endogenous substrate and hence discrete proton-ejecting segments of the respiratory chain could not be identified by measuring $\rightarrow \mathrm{H}^{+} / \mathrm{O}$ quotients in the presence of added substrates (e.g. succinate or ascorbate-TMPD).

$\rightarrow \mathrm{H}^{+} / \mathrm{O}$ quotients were close to $6 \mathrm{ng}$-ion $\mathrm{H}^{+}$(ng-atom $\left.\mathrm{O}\right)^{-1}$ for cells grown under either glucose- or ammonia-limited conditions, but were significantly lower than 6 for cells grown under oxygen limitation (Table 3). Interestingly, the rate of decay of the proton gradient following an oxygen pulse was much more rapid with cells grown under ammonia-limited conditions. However, as a normal rate of decay was later observed with cells grown under $\mathrm{K}^{+}$ limitation (A. Cornish, unpublished), which also produce polymer, it seems likely that the rapid decay rate reflects uptake of $\mathrm{NH}_{4}^{+}$rather than polymer synthesis.

\section{Membrane-bound transhydrogenase activity}

The activity in membranes prepared from glucose-limited cells was $19.7 \mathrm{nmol} \mathrm{min}-1$ (mg protein $)^{-1}$ compared to $93.5 \mathrm{nmol} \mathrm{min}{ }^{-1}$ (mg protein $)^{-1}$ for the NADH oxidase system. As this activity is only approximately $20 \%$ of the rate of $\mathrm{NADH}$ oxidation, site 0 is unlikely to have contributed significantly to the $\rightarrow \mathrm{H}^{+} / \mathrm{O}$ quotients.

\section{DISCUSSION}

The results described above indicate that the respiratory chain of $A$. radiobacter NCIB 11883 is fairly typical of Gram-negative aerobes in that it contains $b$ - and $c$-type cytochromes together with two terminal oxidases $\left(a a_{3}\right.$ and $c o$ ) which can be distinguished by their sensitivity to cyanide, but exhibits only very low transhydrogenase activity. The only apparent change in the respiratory chain as a result of growth under different nutrient limitations occurs in oxygenlimited cells where the activity of the terminal region of the respiratory chain increases approximately fourfold, presumably to compensate for the low ambient concentration of oxygen. This change is probably due to the synthesis of cytochrome oxidase co since it is accompanied by an increase in the concentrations of two membrane-bound polypeptides $\left(M_{\mathrm{r}}\right.$ 29000 and 24000) that stain positively for haem. In this context it is worth noting that cytochrome oxidases co from Azotobacter vinelandii (Jurtshuk \& Yang, 1980), Pseudomonas aeruginosa (Matsushita et al., 1982), Rhodopseudomonas palustris (King \& Drews, 1976) and Methylophilus methylotrophus (Carver \& Jones, 1983; Froud \& Anthony, 1984) contain a $b$-type cytochrome $\left(M_{\mathrm{r}} 29000\right)$ plus a $c$-type cytochrome $\left(M_{\mathrm{r}} 24000 \pm 2000\right)$ and are inhibited noncompetitively by low concentrations of cyanide.

In common with many Gram-negative organisms (Hommes et al., 1984; van Schie et al., 1984), A. radiobacter synthesizes the inactive apoenzyme of quinoprotein GDH. Although the 
function of this enzyme in such organisms is still open to conjecture (see Duine et al., 1986), it is clear that the GDH holoenzyme donates electrons to the respiratory chain via the quinone pool (Beardmore-Gray \& Anthony, 1986), and using membrane vesicles it has been shown that the reconstituted enzyme can generate a protonmotive force in vitro following addition of glucose (van Schie et al., 1985). Linton et al. (1987a) have shown that addition of PQQ to ammonialimited cultures of $A$. radiobacter causes gluconate to be formed at high rates but does not affect the rate of succinoglucan production or the composition of the polymer.

$\mathrm{The} \rightarrow \mathrm{H}^{+} / \mathrm{O}$ quotient of almost exactly 6 which was observed for the oxidation of endogenous substrate by whole cells of $A$. radiobacter grown under ammonia limitation is fully compatible with a respiratory chain that contains cytochrome $c$ but lacks significant transhydrogenase activity, and indicates the presence of three energy coupling sites (Jones, 1977). However, assuming that the nature of the endogenous substrate remains unchanged, the slightly (but significantly) higher and lower values which were obtained with cells grown under glucose- or oxygen-limited conditions respectively suggests that the terminal respiratory chain may be more complex. Indeed, it is tempting to speculate that energy conservation in this region may reflect a variable mixture of a proton-pumping cytochrome oxidase (e.g. $a a_{3}$ ) and a non-proton-pumping cytochrome oxidase which consumes $2 \mathrm{H}^{+}$on the periplasmic side of the membrane (e.g. $c o$ ). Unfortunately, it has not proved possible to carry out a more detailed analysis of the protontranslocating properties of the terminal region of the respiratory chain (e.g. by measuring $\rightarrow \mathrm{H}^{+}$/O quotients with ascorbate-TMPD using initial rate procedures), since we have not been able to deplete the organism of endogenous substrate, and endogenous respiration could not be blocked using classical inhibitors of the cytochrome $b c$ complex (e.g. antimycin $\mathrm{A}$ and hydroxyquinoline $N$-oxide) as these were found to be ineffective.

Since ATP/O quotients of 1.4-1.6 have been estimated from the growth yields of $A$. radiobacter under glucose-limited conditions (Linton et al., 1987b), the $\rightarrow \mathrm{H}^{+} / \mathrm{O}$ quotients reported above are consistent with an overall $\rightarrow \mathrm{H}^{+} /$ATP quotient of approximately $4 \mathrm{~g}$-ion $\mathrm{H}^{+}$ $(\mathrm{mol} \mathrm{ATP})^{-1}$ in this organism.

It is concluded that the energy conservation properties of $A$. radiobacter are not significantly modified during growth under ammonia-limited conditions in an attempt to offset the increased energy demands for exopolysaccharide synthesis.

The authors are indebted to Shell Research Limited for financial support.

\section{REFERENCES}

Beardmore-Gray, M. \& ANTHONY, C. (1986). The oxidation of glucose by Acinetobacter calcoaceticus: interaction of the quinoprotein glucose dehydrogenase with the electron transport chain. Journal of General Microbiology 132, 1257-1268.

Carver, M. A. \& Jones, C. W. (1983). The terminal respiratory chain of the methylotrophic bacterium Methylophilus methylotrophus. FEBS Letters 155 , 187-191.

Duine, J. A., Frank, J. \& Jongejan, J. A. (1986). PQQ and quinoprotein enzymes in microbial oxidations. FEMS Microbiology Reviews 32, 165-178.

Froud, S. J. \& ANTHONY, C. (1984). The purification and characterization of the $o$-type cytochrome oxidase from Methylophilus methylotrophus, and its reconstitution into a 'methanol oxidase' electron transport chain. Journal of General Microbiology 130 , 3319-3325.

Hauge, J. G. (1960). Kinetics and specificity of glucose dehydrogenase from Bacterium anitratum. Biochimica et biophysica acta 45, 263-269.

Hommes, R. W. J., Posma, P. W., Neijssel, O. M., Tempest, D. W., Doktor, P. \& Duine, J. A. (1984). Evidence of a quinoprotein glucose dehydrogenase

apo-enzyme in several strains of Escherichia coli. FEMS Microbiology Letters 24, 329-333.

Hisamatsu, M., OtT, I., Amemura, A. \& Harada, T. (1977). Change in ability of Agrobacterium to produce water-soluble and water-insoluble $\beta$-glucans. Journal of General Microbiology 103, 375-379.

Hisamatsu, M., Sano, K., Amemura, A. \& Harada, T. (1978). Acidic polysaccharides containing succinic acid in various strains of Agrobacterium. Carbohydrate Research 16, 89-96.

JoNES, C. W. (1973). The inhibition of Azotobacter vinelandii terminal oxidases by cyanide. FEBS Letters 36, 347-350.

JONES, C. W. (1977). Aerobic respiratory systems in bacteria. Symposia of the Society for General Microbiology 27, 23-59.

Jones, C. W. \& Poole, R. K. (1985). The analysis of cytochromes. Methods in Microbiology 18, 285-328.

Jones, C. W., Brice, J. M., Downs, A. J. \& Drozd, J. W. (1975). Bacterial respiration-linked proton translocation and its relationship to respiratory chain composition. European Journal of Biochemistry $\mathbf{5 2}$, 265-271.

JURTSHUK, P. \& YANG, T. S. (1980). Oxygen-reactive 
haemoprotein components in bacterial respiratory systems. In Diversity of Bacterial Respiratory Systems, vol. I, pp. 137-159. Edited by C. J. Knowles. Cleveland, Ohio: CRC Press.

KING, M. T. \& DREws, G. (1976). Isolation and partial characterization of the cytochrome oxidase from Rhodopseudomonas palustris. European Journal of Biochemistry 68, 5-12.

LAEMMLI, U. K. (1970). Cleavage of structural proteins during the assembly of the head of bacteriophage $T 4$. Nature, London 227, 680-685.

Linton, J, D., Woodard, S. \& Gouldney, D. G. $(1987 a)$. The consequence of stimulating glucose dehydrogenase activity by the addition of PQQ on metabolite production by Agrobacterium radiobacter NCIB 11883. European Journal of Applied Microbiology and Biotechnology (in the Press).

Linton, J. D., Evans, M. W., Jones, D. S. \& GouldNEY, D. G. (1987b). Exocellular succinoglucan production by Agrobacterium radiobacter NCIB 11883. Journal of General Microbiology 133, 2961-2969.

Matsushita, K., Shinagawa, E., Adachi, O. \&
Ameyama, M. (1982). o-Type cytochrome oxidase in the membrane of aerobically grown Pseudomonas aeruginosa. FEBS Letters 139, 255-258.

Peterson, G. L. (1977). A simplification of the protein assay of Lowry et al. which is more generally applicable. Analytical Biochemistry 83, 346-356.

van Schie, B. J., van Dijken, J. P. \& Kuenen, J. G. (1984). Non-coordinated synthesis of glucose dehydrogenase and its prosthetic group PQQ in Acinetobacter and Pseudomonas spp. FEBS Microbiology Letters 24, 133-138.

Van Schie, B. J., Hellingwerf, K. J., van DiJken, J. P., Elferink, G. L., van DiJl, J. M., Kuenen, J. G. \& Konings, W. N. (1985). Energy transduction by electron transfer via a pyrrolo-quinoline quinonedependent glucose dehydrogenase in Escherichia coli, Pseudomonas aeruginosa and Acinetobacter calcoaceticus (var. Iwoffi). Journal of Bacteriology 163, 493-499.

Thomas, P. E., Ryan, D. \& Levine, W. (1976). An improved staining procedure for the detection of the peroxidase activity of cytochrome P-450 on sodium dodecyl sulphate polyacrylamide gels. Analytical Biochemistry 75, 168-176. 